\title{
The Linkage between Vocational High School Cooperation with Industries in field of Information Technology in Malang.
}

\author{
$1^{\text {st }}$ Kiry a Mateeke Moses \\ Makarere University \\ Kampala Uganda \\ kiryamosesm@gmail.com
}

\author{
$2^{\text {nd }}$ Muladi \\ Lecturer Postgraduate School \\ State University of Malang \\ Malang, East Java Indonesia \\ muladi@gmail.com
}

\author{
$3^{\text {rd }}$ Aji Prasetya Wibawa \\ Lecturer Postgraduate School \\ State University of Malang \\ Malang, East Java Indonesia \\ aji.prasetya.ft@gmail.com
}

\begin{abstract}
Developing potential human resources is every nation's dream through quality education for empowering them for global competition. Skills and knowledge are recognized engines of economic growth and social development in any nation. TVET holds the master key for achieving this growth because it is driven by wheels of training skilled and entrepreneurial workforce needed in workplace with changing technologies as it is concerned with the acquisition of knowledge and skills ready for work. The purpose of this study is to find out the relationship between vocational high schools (S MK) cooperation with industries in the field of I.T in Malang City. This study was conducted in (4) public vocational high schools selected with simple random sampling method with 32 participants. Mixed method was used in data collection with school management and I.T teachers as subject. The results indicated that cooperation between vocational high schools with industries has great impact on the quality of vocational education as seen in the strong positive relationship of this research variables. The common cooperation type that existed were: Internship placement, job recruitment, on-job training.
\end{abstract}

Keywords- Vocational Education, Cooperation, infrastructure \& facilities, Teacher, Student competence \& skills, IT, VHS, TVET.

\section{INTRODUCTION}

Developing a civil society with knowledgeable personality, intelligence and life skills requires quality education. The Indonesian Law No 20 of 2003 explains that: "Education is a conscious and planned effort to develop the potential citizens to have spiritual power, self-control, personality, intelligence as well as skills needed by society, nation and state. This means that, quality human resources has become an ultimatum and obligation for Indonesia. Vocational education and training (VET) is perceived the master key for realizing this. The National Law no. 20 of 2003 on the National Education System article 15, explains that "Vocational Education is an education system for preparing students to work in particular fields". It is education intended for graduates of SMK to be ready for work in certain fields of expertise [1] [2].
Similarly, the Government Regulation No. 29 of 1990 states that vocational education is the development of students' ability to carry out certain types of work with the priority in preparing the students to enter the workforce with a developed professional attitude. Also, vocational high schools establish educational programs that are designed to particular types of employment or trains people for work [3].

Vocational education and training at the secondary level has been rapidly expanding in Indonesia over the last decade of the development of TVET according to Prayono, (2011: 124) as cited in [4]. This has been the case of senior secondary level where enrollment in vocational education is increased by $158 \%$ between 2001 and 2010 . The government has focused on this sector as a key strategy for economic development though it has the challenge of matching the skills of the students to current and future economic demands $[5,6]$. The Indonesian government through the Ministry of Education and Culture is efforts of attaining complete transition of students' enrolment ratio of general high school (SMA) to vocational high school (SMK) from 70:30 to 30:70 respectively implying that currently the government values more of vocational education to general education with the purpose of improving their human resource development with quality skills and knowledge.

According to [7], vocational high schools in Indonesia are directed to the goals of preparing students to be ready as workers and developing their professional attitude. To reach these goals, dual system education has been established as a public policy in the form of professional skill education. Also the strength and success of vocation high school education lies in nature of their cooperation with industries. According to Ghost stated that "to ensure the relevance of learning in school education, educators need to understand how workplace skills are continually changing" [8]. This means that the schools should know the current trends in the industries especially in workplace skills and dispositions while industries should know school activities and how to contribute to skill development thus requiring 
knowledge sharing. Therefore this makes school-industry cooperation very important.

According to Rediyono as cited in [9] says "Cooperation between the school and industry is very necessary in connection with technological development in the industry very rapidly so that the school would be far behind if it is not cooperating with the industry because the school is not possible to provide all the equipment in accordance with the needs of industry in the learning process in schools. In addition, cooperation with industry will also assist in distributing school graduates because the industry already know the extent of competences of the graduates of the school who have been cooperating with the industries concerned".

Thus in conclusion, in order for vocational high schools to improve the employability skills and competences of their graduates to be ready to provide workforce in the labor market upon graduation, they must build a strong linkage of cooperation with industries since industries are potential employers of school products. Vocational High School is a secondary education program with the aim of preparing graduates who do not continue for higher education to be more ready for work with competence owned in their fields [1]. Vocational High School (VHS / SMK) are institutions mandated by law to prepare graduates ready for work or to enter the workforce becoming productive workforce especially in industries. Hence vocational schools are expected to have competitiveness, opportunity and ability to prepare ready-made workers in community life [10].

Conversely, this contradicts the results from the preliminary research observation conducted on November 2016 in nine (9) both public and private SMK in Malang city showed that many graduates from SMK are not all easily absorbed by the industries as assumed by its vision and objectives due to: mismatch (skills gap) in SMK programs and industries' needs and demands; weaknesses in curriculum design; incompetent teachers with limited industrial training and experience; large amount of annual graduates and inadequate up to date learning facilities and infrastructure in vocational schools (SMK).

Building on this, the data from the National Labor Force Survey (Sakernas) indicates that the unemployment figure in February 2016 reached more than 7 million people with the highest unemployment rate by level of education dominated by the graduates of general high school (22\%) and SMK (19.19\%), junior high $(18.70 \%)$, elementary (17.35\%), while for University (9.90\%) and Diploma 3: $30 \%$ ) this therefore indicates that the rate of absorption of vocational graduates is still very low.

This observation is supported by the speech of $\mathrm{Mr}$. Sumarna Abdurrahman the head of the National Board for Professional Certification (BNSP) who said; "Although, it is assumed that Technical and vocational education and training (TVET) or SMK programs are designed to prepare learners to profit and progress through it however, one of the problem facing TVET in Indonesia is the curricula failure to reflect the actual needs of industries. According to the
National Board for Professional Certification (BNSP), the quality and competitiveness of vocational high school (SMK) graduates is still low. BNSP head Sumarna Abdurrahman says "our workforce is not much absorbed by the industry" adding that the quality of the workforce is influenced by different learning experience during the internship program and they finally face the real work. However, Sumarna expects the government to adjust SMK curriculum with standards developed by industry as well as Sumarna sees partnership between SMK and industry is essential"' $[11,12]$.

Furthermore, Jakarta Post 2016 in Press Reader.com [13], reported that every year 1.3 million SMK graduate students from over 12,000 vocational schools across the archipelago. Meanwhile, the population of SMK graduates according to Malang Education head office report 2016, is about 8,937 students who graduate every year which rises the competition for jobs vacancies in the industries hence leaving out many without work. Similarly, the official data shows that the unemployment rate of SMK graduates is higher than that of graduates of all other educational institutions. The Central Bureau of Statistics (BPS) [14] August 2015 reported that, 12.65 percent of vocational school graduates were unemployed.

Therefore, from the preliminary observation in 9 SMK in Malang, results supported by this evidence shows that the major problems of SMK graduates are; Skills gap (mis match or link and match) between SMK curriculum and the industry needs, lack of field experiences by teachers, inadequate update learning facilities especially the equipment for school practices and stiff competition. Therefore, in order for SMK to improve the competence and quality of its graduates, it should establish and implement cooperative relationship with Industries.

It is noted that the key to the success of effective vocational education and training is the engine of the curriculum, upgrading teacher / instructor skills with work sabbaticals or opportunities to interface more closely with industry, industry oversight in student Assessment, and ensuring that SMK facilities and tools keep pace with the latest technological developments of industry $[4,5]$.

According to an employer / employee survey (2008) on the quality of graduates from vocational senior secondary schools (SMKs), they have inadequate understanding of the curriculum which is not industryspecific. This criticism reflects the quality of the vocational education and training (VET) teachers employed and their qualifications [4, 5]. Also, Employers report that the curriculum of vocational schools is not based on some of the skills providers $[4,5]$

There are also reasons why SMK education has poorly coordinated with labor market demands which include; (1) ineffective co-operation with industry in planning and developing the curriculum; (2) few industries co-operate with SMK in the provision of facilities and equipment; (3) limited access to labor market information by 
SMK graduates; (4) inadequate number of teachers with industrial work experience in their areas of specialization.

It is also confirmed by findings of the literature that there is little way of managing or removing underperforming teachers $[4,5]$. The quality and qualifications of teachers are important if students are to learn successfully. Thus a strong linkage between SMK cooperation with industries is the solution to these challenges.

From the above discussions, the objective of this research study; finding out the connection between vocational high school cooperation with industries in terms (i) school infrastructure and facilities, (ii) teacher competence and skills and (iii) student competence and skills, the problem statement of this research study can be formulated into these research questions applicable in this study as below:

1. How does the industry support vocational high schools in terms of Infrastructure \& Facilities as a link to cooperation?

2. How does the industry support the school in improving teacher's competence and Skills in IT as a link to cooperation?

3. How does vocational high schools get industrial support in terms of improving Student's competence and skills in IT as a link of cooperation?

4. What forms of cooperation exists between this school with industries in the department of information technology and what is the cooperation process?

\section{METHOD}

This research is a quantitative and qualitative descriptive research with correlational approach. The research population 48 people from school management and I.T teachers of public SMK in Malang City with program study of TKJ, RPL, and MM. Simple random sampling technique was used to select the sample $[15,16,17]$. Sample size of this research is 32 respondents with 8 participants from each SMK. The research study was conducted to investigate the linkage between vocational high school cooperation in the field of information technology in Malang city. This research used both primary and secondary data sources through closed ended questionnaire administration and the school documentations. Qualitative approach was carried out through a brief face to face interview with respondents as a support to the questionnaire results. Descriptive Statistics were applied in the presentation and analysis of the empirical results. Before the instrument were used to collect data, validity and reliability tests were carried out. The construct validity test of the questionnaire was carried out by consulting the supervisor regarding the suitability of each indicator used in the instrument. Data was analyzed with the help of SPSS, while for the reliability test using Alpha Cronbach scale test.

\section{A. Results}

From the questionnaire returned, research findings show that school-industry cooperation exists mainly in the two research variables that is to say: teacher competence and skills; student competence and skills; well as in school infrastructure and facilities, there is little or no significant cooperation identified from the collected data although through face to face interview of respondents agreed that cooperation with industries in this area also is important. This can be identified from the results of high mean values $(\mathrm{X} 1=69.22, \mathrm{X} 2=70.06, \mathrm{X} 3=69.34$, and $\mathrm{Y}=68.03)$. Also, Pearson correlation analysis on each independent variable with the dependent variable known correlation value between variables are as follows. The correlation between SMK with industries in terms of infrastructure and facilities is 0.634 with the $\operatorname{sig}$ value (p) 0.000 . The correlation between SMK with industries in terms of improving teacher's competence and skills was 0.702 with the sig value (p) 0.000 . The correlation between SMK cooperation with industries in terms of improving student's competence and skills is 0.739 with the sig value. (p) 0,000 .

From the correlation between SMK with industries in terms of infrastructure and facilities ( 0.634 or $63.3 \%$ ) shows moderate positive relationship at sig value (p) 0.000 . This means the sig value $(\mathrm{p}=0.000)<0.05$, and it can be concluded that relation between SMK with industries in terms of infrastructure and facilities is essential. Also, correlation between SMK with industries in terms of improving teacher's competence and skills ( 0.702 or $70.2 \%$ ) implies that there a strong positive relationship with sig value. (p) 0.000. Because the sig. (p) value is less than 0,05, it implies a strong positive and significant relation between SMK with industries in terms of improving teacher's competence and skills. And finally from the correlation between SMK cooperation with industries in terms of improving student's competence and skills ( 0.739 or $73.9 \%$ ). This means a strong correlation with positive relationship since the value of $\mathrm{r}$ is also positive while sig value. $(p=0,000)<0,05$ thus can be concluded that correlation in this aspect is essential.

\section{B. Discussion}

In reference with the existing literature reviews, the results of this study showed that; there was no significant relationship between vocational high school cooperation with industries in terms of infrastructure and facilities in reality since all schools have no infrastructure support from industry but all their infrastructure was established with support from government $[18,19,20]$ however, the significant and positive relationship was more noticed in teacher's competence and skills; and student's competence and skills. Lastly, the common forms of cooperation between SMK and industries were: internship placement, recruitment, curriculum synchronization, guest lectures, student's ass essment and on-job training, teacher internship, workshops etc.

\section{CONCLUSION}

From this research findings, it can be clearly seen that cooperation between vocational high school with industries is crucial for both institutions (the schools and 
industries) because it enables the industry to get the competent and knowledgeable workforce at reduced costs since industry without knowledge cannot thrive to live; improving the public reputation; it enables SMK to produce quality output with updated curriculum based on the industry needs, internship placements. It also indicated that there was stronger positive and significant relationship between vocational high schools with industries in teacher's competence and skills as well as student's competence and skills $(70.2 \%$ and $73.9 \%$ respectively).

The suggested recommendations from this study are: establishment of teaching factory for information technology department in all other vocational high schools which have not yet established; increase in duration of internship placement from 3-6 months to at least minimum of one (1) year during the period of their programs; vocational high schools should also seek cooperation with international factories or industries that operate internationally to widen the employability opportunities of their graduates in the global market; inclusion of both private vocational high schools and all stakeholders as the subject of the study.

\section{ACKNOWLEDGMENT}

1. I would like to extend my sincere gratitude to the Directorate of Higher Education Indonesia (DIKTI) through KNB program for the financial support that enabled the completion of this study.

2. I also acknowledge the support of school management and all my respondents from SMK N 2 Malang, SMK N 3 Malang, SMK N 8 Malang and SMK N 10 Malang for accepting my request to carry out my research in their schools and also participating during the research study.

3. Finally, I acknowledge the support from all my colleagues from Postgraduate School - UM for their encouragements, critics and valuable advice during the course program. It has been a wonderful and great moment with you guys.

\section{REFERENCES}

[1] Azizah, 2015. Strategi Kerjasama Sekolah Dengan Dunia Usaha Dan Dunia Industri (Du/Di) Dalam Meningkatkan Kompetensi Lulusan Pada Smk Negeri 3 Banda Aceh

[2] Dian Fitri Perwitasari, 2013. Relationship of TKJ Practicum Facility in School, Conformity Place Prakerin, and TKJ Competence of Students with Skill Competency Test Results)

[3] Sonhadji (2013). Manusia, Teknologi dan Pendidikan Menuju Peradaban Baru. Malang:UM Press.

[4] Abdullah Helmy (2014). VET Training and Industry Partnerships: A study in East Java, Indonesia.

[5] INAPEN, 2015. AEC will begin, the graduates of Vocational High School must be ready to compete $\mathrm{http}: / /$ www.inapen.ac.id/read/article/11/aec-will-begin-the-graduatesof-vocational-high-school-must-be-ready-to-compete/en

[6] OECD/Asian Development Bank (2015). Education in Indonesia: Rising the Challenge. https://www.adb.org/sites/default/files/.../education-indonesia-risingchallenge.pdf downloaded on 25/1/2017

[7] OECD/ADB (2015). Reviews of National Policies for Education: Education in Indonesia Rising to the challenge.

[8] Mohammad Maskan (2014). Paired Industrial Role in the Implementation of Dual System Education to Shape the Work Adaptability of Vocational High School Students in Greater Malang.

[9] James J Watters, 2013. School Industry Partnerships: An Innovative Strategy for Vocational Education

[10] Dewi Kurniasari, 2015. Analisis Pelaksanaan Kerjasama SMK dengan Dunia Usaha. UM

[11] BNSP (2015). Kualitas Tenaga Lulusan SMK Belum Sesuai yang Diharapkan Industri http://www.berit asatu.com/pendidikan/312762bnsp-kualitas-tenaga-lulusan-smk-belum-sesuai-yang-diharapkanindustri.html,

[12] BNSP, (2015). Quality of SMK Graduates is Below Industry's Expectation www.acdp-indonesia.org/.../bnsp-quality-of-smkgraduates-is-below-industrys-expect .

[13] PressReader.com, Jakarta Post (2016). SMK graduates lose shine over skills gap. https:/www.pressreader.com/

[14] Djandji Purwanto, 2013. Management of Cooperation between industry and Vocational High School: SMK 1 Singosari Malang Heavy Equipment.

[15] Sugiyono (2011). Educational Research Methods. Bandung Alfabeta

[16] Sugiyono (2012). Statistics for Research. Bandung Alfabeta.

[17] John W. Creswell, 2014. Research Design: qualitative, quantitative, and mixed methods approaches. 4 th ed.

[18] Law Number 20 Year 2003 on National Education System. 2003. Jakarta: Sinar Grafika Offset.

[19] Depdiknas. 2008b. Enclosure of Ministerial Decree No 40 Year 2008 regarding standard of facilities and infrastructure of SMK / MAK. Jakarta: Ministry of National Education.

[20] Government Regulation Number 19 Year 2005 on National Standards of Education. Jakarta: Sinar Grafika Offset. 